\title{
RECONNAISSANCE RE-OS ISOTOPE STUDY OF INDIAN KIMBERLITES AND LAMPROITES: IMPLICATION FOR THEIR MANTLE SOURCE REGIONS
}

\author{
N.V.CHALAPATHI RAO ${ }^{*}$, R.A.CREASER ${ }^{2}$ and B. LEHMANN ${ }^{3}$ \\ ${ }^{1}$ Centre of Advanced Study in Geology, Banaras Hindu University, Varanasi, 221005, India (*E-mail: $\underline{\text { nvcr100@gmail.com })}$ \\ ${ }^{2}$ Dept. Earth \& Atmospheric Sciences, University of Alberta, Edmonton Alberta T6G2R3, Canada \\ ${ }^{3}$ Mineral Resources, Technical University of Clausthal, 38678 Clausthal-Zellerfeld, Germany
}

The nature of the mantle reservoirs of kimberlites and lamproites and their depths of derivation are controversial and debatable. The favoured source regions of the kimberlite ranges from core-mantle boundary (Torsvik et al., 2010; Collerson et al., 2010) and transition zone (Ringwood et al., 1992), through asthenosphere (Mitchell, 2006) to sub-continental lithospheric mantle (Tainton and McKenzie, 1994; Le Roex et al., 2003) with some of the most recent models favouring involvement of multiple reservoirs including cratonic- as well as sub-lithospheric sources (Tappe et al., 2011). An analogous scenario prevails for lamproites as well with their envisaged sources varying from sub-lithospheric (Murphy et al., 2002) and sub-continental lithospheric (Mirnejad and Bell, 2006) mantle.

Many previous studies involved trace elemental abundances, their ratios, experimental studies and various radiogenic isotope systems $(\mathrm{Nd}-\mathrm{Sr}-\mathrm{Hf}-\mathrm{Pb})$ to constrain the source regions of kimberlites and lamproites (e.g., Smith, 1983; Chalapathi Rao et al., 2004; Becker and Le Roex, 2006; Chakrabarti et al., 2007; Woodhead et al 2009). However, in recent years the ${ }^{187} \mathrm{Re}^{187} \mathrm{Os}$ system has been used to chemically fingerprint distinct reservoirs. The compatibility of Os (wherein it becomes concentrated in the peridotitic portions) and incompatibility of Re (preference for a melt phase) during partial melting of the mantle leads to large variation in $\mathrm{Re} / \mathrm{Os}$ ratios between mantle and crust, as well subsequent Os isotopic composition in crust and mantle. The high mantle Os content may renders it relatively immune to influence of metasomatic processes relative to other isotope systems such as $\mathrm{Sr}, \mathrm{Nd}$ and $\mathrm{Pb}$ (Shirey and Walker, 1998; Carlson, 2005).

Substantial Re-Os isotopic data is available for the mantle-derived spinel and garnet peridotite xenoliths (e.g., Carlson et al., 2007; Schilling et al., 2008; Rudnick and Walker, 2009) entrained by kimberlites and other alkaline magmas. However, such data is relatively sparse for the host potassic -ultrapotassic continental magmas and limited to a few occurrences such as those from Yilgarn craton, Australia (Graham et al., 1999), Italian peninsula (Conticelli et al., 2007), S.W. Arkansas, U.S.A. (Lambert et al., 1995), Alto Paranaiba Province, Brazil (e.g., Carlson et al., 1996; Araujo et al., 2001) and southern African kimberlites (Pearson et al., 2008).

The main purpose of this paper is to report reconnaissance Re-Os isotopic data for the Mesoproterozoic kimberlites and lamproites from the Eastern Dharwar craton, southern India and end-Cretaceous Kodomali orangeite from the Bastar craton, central India. Contrasting petrogenetic models exist as to the depths of derivation of kimberlite and lamproite samples incorporated in this study (e.g., Chalapathi Rao et al., 2004; Chalapathi Rao et al., 2010; Chakrabarti et al., 2007; Paton et al., 2009; Patel et al., 2010) and their genesis has been investigated via a Re-Os isotopic perspective. 


\section{0 $^{\text {th }}$ International Kimberlite Conference, Bangalore - 2012}

Finally, we compare the data obtained from this study with that of global occurrences to decipher their similarities and differences.

The kimberlites, lamproites and orangeite investigated in this study are well characterised in terms of their petrography and mineralogy and details are available in the literature (Fig.1 A and B): Pipes P-10, P-11, P-12, CC-3, CC-4, CC-5 and KL-3 from the Wajrakarur kimberlite field (WKF) (Neelakantam, 2001; Paul et al., 2006; Chalapathi Rao et al., 2004; Chalapathi Rao and Srivastava, 2009); SK-1 from the Raichur kimberlite field (RKF) (Sridhar et al., 2004; Chalapathi Rao et al., 2010); KK-6 from the Narayanpet kimberlite field (NKF) (Chalapathi Rao and Dongre, 2009); Kodomali (KDK-2) from Mainpur orangeite field (Chalapathi Rao et al., 2011a) and Ramapuram, Pochampalle and Reddikunta lamproites from the Krishna lamproite field (KLF) (Reddy et al., 2003; Paul et al., 2007; Chalapathi Rao et al., 2010).

The ${ }^{187} \mathrm{Os} /{ }^{188} \mathrm{Os}_{\mathrm{i}}$ isotopic data of WKF, NKF and RKF samples are corrected for their emplacement age of $1100 \mathrm{Ma}$ whereas the lamproite data has been age corrected to 1225 and $1500 \mathrm{Ma}$. The sole orangeite sample is age corrected to 65Ma. Various parameters such as gOs (which is the percentage between the Os isotopic composition of a sample and the average chondritic composition for a specific time), $\mathrm{T}_{\mathrm{MA}}$ or model age (time of separation from mantle that is growing according to chondritic evolution) and $\mathrm{T}_{\mathrm{RD}}$ or Re-depletion model age (time of $\mathrm{Re}$ depletion which is considered to be the minimum age) are calculated as per the equations given in Shirey and Walker (1998) and Carlson (2005).

The Re concentration of the kimberlites ranges from 0.077 to $0.290 \mathrm{ppb}$ whereas the Os content varies from 0.311 to $1.98 \mathrm{ppb}$. The measured ${ }^{187} \mathrm{Os} /{ }^{188} \mathrm{Os}$ ratios for all except one sample (KL3/1) are higher than chondritic modern mantle $(0.13-0.16)$, and the calculated initial ${ }^{187} \mathrm{Os} / 188 \mathrm{Os}$ ratios range from 0.0967 to 0.1260 . The kimberlites show variable depletion in their

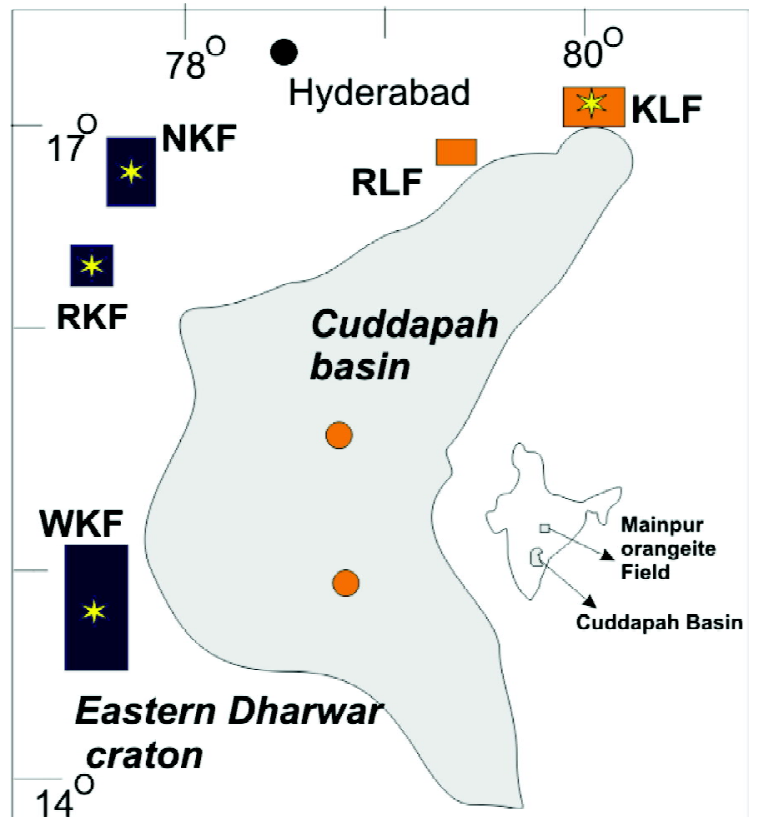

$120 \mathrm{~km}$

Figure 1A Location map of the Cuddapah basin and Eastern Dharwar craton in southern India showing the kimberlites/lamproites sampled in this study.

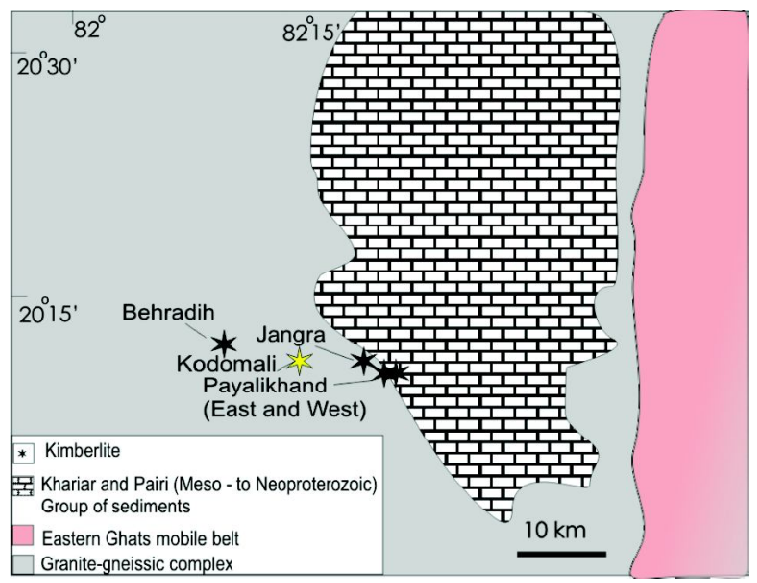

Figure 1B Geological map of the Mainpur orangeite field in the Bastar craton showing the location of Kodomali pipe sampled in this study (adapted from Chalapathi Rao et al., (2011a).

${ }^{187 / 188}$ Os relative to chondrite (at $1100 \mathrm{Ma}$ ) as expressed by the -ve gOs parameter, and for three samples (CC $3 / 1, \mathrm{CC} 3 / 2$ and $\mathrm{P} 11 / 1)$ this value is very low, nearly -20 . This is close to the meteorite 


\section{0 $^{\text {th }}$ International Kimberlite Conference, Bangalore - 2012}

initial Os at $4.6 \mathrm{Ga}$ (i.e., impossible) and likely means that for these samples, present day $R e$ is too high and may have been added/altered. However, two of the kimberlite samples (Raichur and Narayanpet fields) and the Kodomali orangeite show positive ã Os values ranging from +4.2 to +4.9 which imply slightly radiogenic mantle sources. The Kodomali orangeite has a slightly higher initial ${ }^{187} \mathrm{Os} /{ }^{188} \mathrm{Os}$ ratio of 0.1330 . On the other hand, the lamproites display much lower $\operatorname{Re}(0.031$ to $0.279 \mathrm{ppb})$ and Os (0.060 to $0.129 \mathrm{ppb}$ ) contents and their initial ${ }^{187} \mathrm{Os} /{ }^{188}$ ratios are significantly higher, i.e. in the range of 0.1891 to 0.5499 than those of kimberlites, with very radiogenic ãOs values of +59 to +361 .

The results obtained in this study demonstrate that Re-Os abundances as well as the ${ }^{187} \mathrm{Os} /{ }^{188} \mathrm{Os}$ isotopic ratios are markedly different for kimberlites and lamproites. The Os abundances of the kimberlites (0.311-1.94 ppb) are clearly higher than those in lamproites $(0.060$ $-0.129 \mathrm{ppb}$ ) but all of their Re contents (0.054$0.290 \mathrm{ppb}$ ) are indistinguishable. All the kimberlites and orangeite essentially have $\mathrm{Re} / \mathrm{Os}$ $<1$ and are strikingly similar to those of the Mesozoic kimberlites and orangeites from the Kaapvaal craton, southern Africa and also show overlap with those of Palaoproterozoic kimberlites from the Eastern Gold field province, Yilgarn craton, Australia; whereas lamproite samples are confined to the compositional field of those from the Italian peninsula (Graham et al., 2004; Conticelli et al., 2007; Fig.2). The initial ${ }^{187} \mathrm{Os} /$ ${ }^{188} \mathrm{Os}$ isotopic ratios and Os abundances of the kimberlites and orangeite of this study are also remarkably similar to those from the Alto Paranaiba alkaline Province, Brazil (Carlson et al., 1996; Aruajo et al., 2001) on the other hand, the lamproites from KLF share similar compositions as those from Italian peninsular and to some extent with those from the Alto Paranaiba alkaline Province (Fig.3). Importantly, the initial ${ }^{187} \mathrm{Os} /{ }^{188} \mathrm{Os}$ isotopic ratios of the samples of this study are very different from those of the

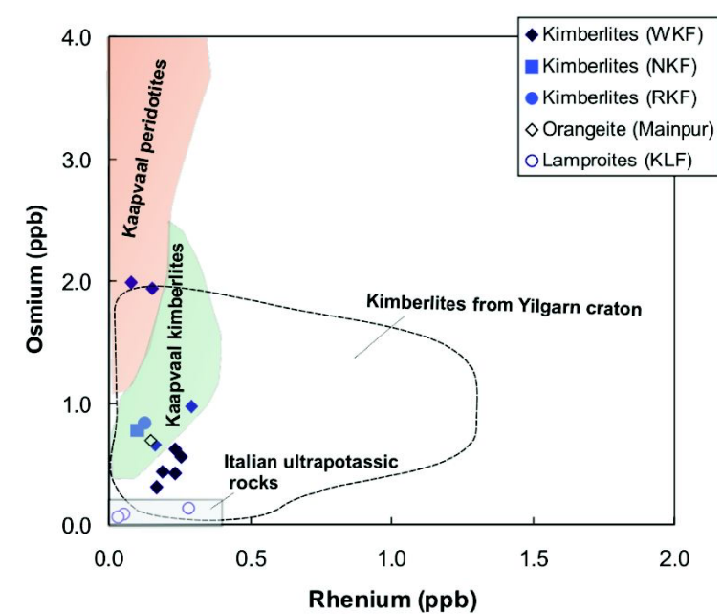

Figure 2 Re vs Os concentration diagram for the samples of this study. The fields for Kaapvaal peridotites and kimberlites and those for Yilgarn craton kimberlites are from Graham et al (2004) and the field for Italian ultrapotassics is from Conticelli et al., (2007).

continental crust shown for a comparison in Fig.3 and thus exclude significant crustal contamination.

The negative $\gamma \mathrm{Os}$ of WKF kimberlite samples therefore imply derivation of Os from a depleted or unradiogenic source with long-term lowered ${ }^{187} \mathrm{Re} /{ }^{188} \mathrm{Os}$ source such as previously melt-depleted subcontinental lithosphere. However, several samples show unrealistically low Os values, despite realistic measured ${ }^{187} \mathrm{Os} /$ ${ }^{188} \mathrm{Os}$ values, implying that the age-correction based on measured $\mathrm{Re} / \mathrm{Os}$ ratios is inaccurate for some samples. In particular, three samples (CC3/

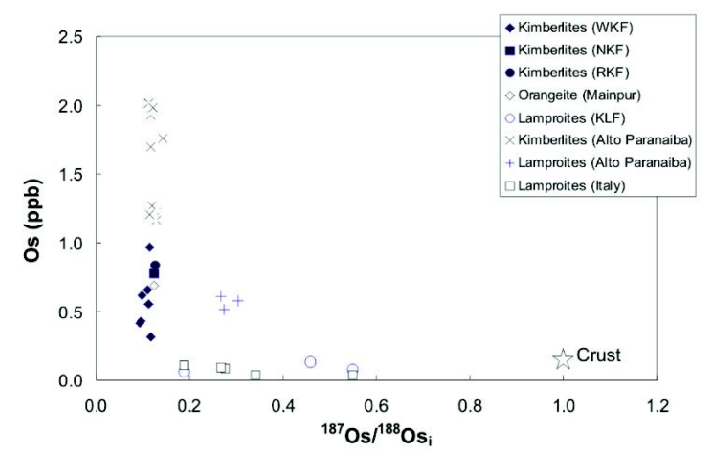

Figure $3{ }^{187} \mathrm{Os} /{ }^{188} \mathrm{Os}_{\mathrm{i}}$ versus Os (ppb) diagram for the samples of this study. The data for Alto Paranaiba kimberlites and lamproites is from Carlson et al., (1996) and Aruazo et al., (2001). The data for Italian lamproites as well as the composition of Crust is from Conticelli et al., (2007). 


\section{0 $^{\text {th }}$ International Kimberlite Conference, Bangalore - 2012}

$1, \mathrm{CC} 3 / 2$ and P11/1) appear to have vastly lower $\gamma \mathrm{Os}$ than most remaining samples, which range from -1 to -8 . The degree to which this correction bias affects each sample is difficult to quantify, but the most Re-depleted sample (KL3/1) with lowest present day ${ }^{187} \mathrm{Os} /{ }^{188} \mathrm{Os}(0.1143)$ and lowest ${ }^{187} \mathrm{Re} /{ }^{188} \mathrm{Os}$ ratio $(<0.2)$ has an $\gamma \mathrm{Os}$ of -7 and yields a model age $\left(\mathrm{T}_{\mathrm{MA}}\right)$ of $3.4 \mathrm{Ga}$ and a Re-depletion age $\left(\mathrm{T}_{\mathrm{RD}}\right)$ of $1.9 \mathrm{Ga}$. The age correction for this sample is minimal, and as such the resulting $\gamma \mathrm{Os}$ value likely to be the most reliable. The $T_{R D}$ depletion age of $1.9 \mathrm{Ga}$ point to the involvement of Proterozoic lithosphere in the genesis of the kimberlites and it strikingly corresponds with the $\mathrm{Nd}$ model ages of the Krishna and Cuddapah lamproites (Chalapathi Rao et al., 2004, 2010 and Osborne et al., 2011) but also the emplacement of Large igneous provinces of similar age and magmatism in the Dharwar and Bastar cratons (India), the Superior Craton (Canada) and the Kaapvaal craton (southern Africa; French et al., 2007). The argument for a Proterozoic lithosphere as source region for the EDC kimberlites is also supported by the similarity of $\mathrm{T}_{\mathrm{RD}}$ depletion age with that of Nd-depleted mantle model ages of 1.4-1.6 Ga recently determined on their perovskites (Chalapathi Rao et al., 2012).

The KK6/1 (NKF), SK1(RKF) and KDK-2 (Mainpur orangeite) samples have +ve $\gamma \mathrm{Os}$ values that are considered as enriched or radiogenic and imply derivation long term elevated ${ }^{187} \mathrm{Re} /{ }^{188} \mathrm{Os}$ sources (Walker and Shirey, 1998). An enriched mantle source for the Mainpur orangeites is additionally supported by their $\varepsilon \mathrm{Nd}_{\mathrm{i}}$ values that range from -6.4 to -10.4 which imply derivation dominantly from melt source regions with lower time-integrated $\mathrm{Sm} / \mathrm{Nd}$ ratios than Bulk Earth (Lehmann et al., 2010; Chalapathi Rao et al., 2011b). Likewise, the slightly radiogenic nature of ${ }^{187} \mathrm{Os} /{ }^{188} \mathrm{Os}$ isotopic ratios displayed by $\mathrm{KK} 6 / 1$ (NKF) and SK1(RKF) are also supported by their geochemical distinctness, compared to other EDC occurrences, which has been explained to be due to involvement of mixed (plume and subduction- related) source regions in their genesis (Chalapathi Rao and Dongre, 2009 and Chalapathi Rao et al., 2010). The involvement of a metasomatised subcontinental lithospheric mantle in the generation of EDC kimberlites and Mainpur orangeite is also strongly supported by $\mathrm{Re} / \mathrm{Os}$ vs $\gamma \mathrm{Os}$ plot (Fig.4) wherein their compositions are strikingly similar to those of the metasomatised Archaean

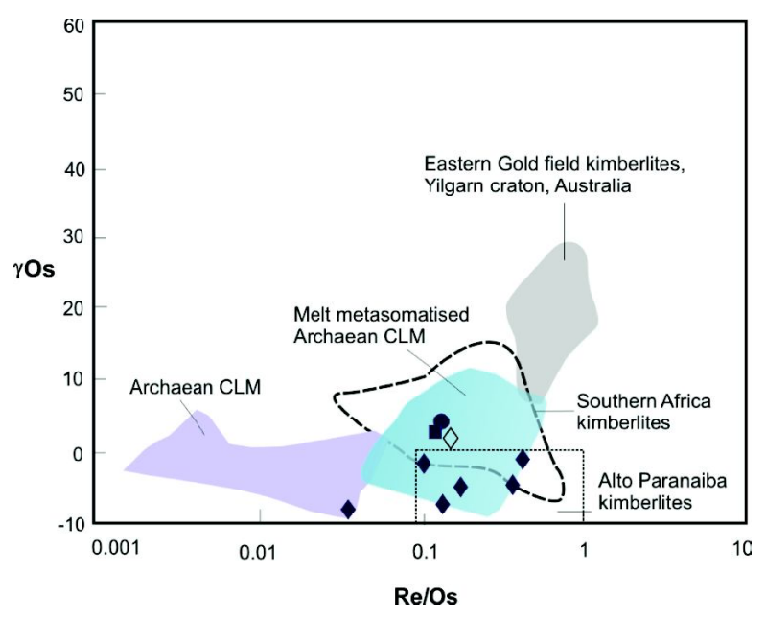

Figure $4 \mathrm{Re} / \mathrm{Os}$ versus gOs for the samples of this study. Various fields are taken from Graham et al., (2004) and the field for Alto Paranaiba kimberlites is from Calrson et al., (1996) and Aruajo et al., (2001).

lithospheric mantle and kimberlites from southern Africa and Alto Paranaiba Province. A broad similarity in ${ }^{187} \mathrm{Os} /{ }^{188} \mathrm{Os}$ between southern African kimberlites and Kaapvaal peridotites was also highlighted by Pearson et al., (2008).

The KLF lamproite samples, on the other hand, are clearly very different, with very radiogenic $\gamma$ Os values $(+59$ to +369$)$, indicated high $\mathrm{Re} / \mathrm{Os}$ materials in their source, possibly subducted component in their source region, and have a strong similarity to the compositions of subduction-related lamproites of Italian peninsula and also those from Alto Paranaiba alkaline province (Figs. 2 and 3). However, they are different from the non-radiogenic initial $\gamma \mathrm{Os}$ values of -3.2 to -3.6 and -2 to -6 reported for the 106Ma Prairie Creek lamproites, S.W. Arkansas, U.S.A (Lambert et al., 1995) and 1200 Ma Argyle 


\section{0 $^{\text {th }}$ International Kimberlite Conference, Bangalore - 2012}

lamproite, Western Australia (Graham et al., 1999) respectively implying their distinct genesis. Our results provide compelling evidence for an isotopically heterogeneous lithospheric mantle sources for the Mesoproterozoic kimberlites and lamproites in and around the Cuddapah basin and Eastern Dharwar craton inferred earlier from $\mathrm{Nd}$ isotopic systematics (Chalapathi Rao et al., 1998, 2004).

Our proposal, from a $\mathrm{Re}-\mathrm{Os}$ isotopic perspective, for the involvement of SCLM in the generation of Indian kimberlites, lamproites and orangeites is also consistent with most recent models which invoke involvement of multiple sources for such rocks from southern Africa (Le Roex et al., 2003; Becker and Le Roex, 2006; Donnelly et al., 2011) and Greenland (Tappe et al., 2011).

\section{References}

ARAUZO A.L.N., CARLSON, R.W., GASPAR, J. C. and BIZZI, L.A.

(2001) Petrology of kamafugites and kimberlites from the Alto Paranaiba Alkaline Province, Minas Gerais, Brazil. Contributions to Mineralogy and Petrology v.142, pp. 163-177.

BECKER, M. and LE ROEX, A.P. (2006). Geochemistry of South African on- and off-craton Group I and II kimberlites: Petrogenesis and source region evaluation. Journal of Petrology v.47, pp. 673-703.

CARLSON, R.W. (2005) Application of the Pt-Re-Os isotopic systems to mantle geochemistry and geochronology. Lithos, v.82, pp. 249-272.

CARLSON, R.W., ESPERANCA, S. and SVISERO, D.P. (1996) Chemical and Os isotopic study of Cretaceous potassic rocks from southern Brazil. Chemical and Os isotopic study of Cretaceous potassic rocks from southern Brazil. Contributions to Mineralogy and Petrology v.125, pp. 393-405.

CARLSON, R.W., ARAUJO, A.L.N., BROD, T.C.J., GASPAR, J.C., BROD, J.A., PETRINOVIC, I.A., HOLLANDA; M.H.B.M., PIMENTEL, M.M. and SICHEL, S. (2007) Chemical and isotopic relationships between peridotite xenoliths and mafic-ultrapotassic rocks from southern Brazil. Chemical Geology v.242, pp. 418-437.

CHAKRABORTI, R., BASU, A.R. and PAUL, D.K. (2007) Nd-Hf-Sr-Pb isotopes and trace element geochemistry of Proterozoic lamproites from southern India: subducted komatiite in the source. Chem. Geol., v. 236, pp. 291-302.

CHALAPATHI RAO, N.V. and DONGRE, A. (2009) Mineralogy and geochemistry of kimberlites NK2 and KK-6, Narayanpet kimberlite field, Eastern Dharwar craton, southern India: evidence for a transitional (South African) kimberlite signature. Canadian Mineralogist v.47, pp.855-873.

CHALAPATHI RAO, N.V. and SRIVASTAVA, R.K. (2009) Petrology and Geochemistry of Diamondiferous Mesoproterozoic kimberlites from Wajrakarur Kimberlite Field, Eastern Dharwar Craton, Southern India: Genesis and constraints on mantle source regions. Contributions to Mineralogy and Petrology v.157, pp.245-265.

CHALAPATHI RAO, N.V., GIBSON, S.A., PYLE, D.M. and DICKIN, A.P., (2004) Petrogenesis of Proterozoic lamproites and kimberlites from the Cuddapah Basin and Dharwar Craton, southern India. Journal of Petrology v.45, pp. 907-948.

CHALAPATHI RAO, N.V., DONGRE, A.N., KAMDE, G., SRIVASTAVA, R.K., SRIDHAR, M., KAMINSKY, F.E. (2010) Petrology, geochemistry and genesis of newly discovered Mesoproterozoic highly magnesian, calcite-rich kimberlites from Siddanpalli, Eastern Dharwar craton, Southern India: products of subduction-related magmatic sources? Mineralogy and Petrology v.98, pp.313328.

CHALAPATHI RAO, N.V., LEHMANN, B., MAINKAR, D. and BELYATSKY, B. (2011a) Petrogenesis of the end-Cretaceous diamondiferous Behradih orangeite pipe: implication for mantle plume-lithosphere interaction in the Bastar craton, Central India. Contributions to Mineralogy and Petrology v.161, pp. 721-742.

CHALAPATHI RAO , N.V., PATON, C. and LEHMANN, B. ( 2011b) Origin and diamond prospectivity of Mesoproterozoic kimberlites from the Narayanpet field, Eastern Dharwar craton, southern India: insights from groundmass mineralogy, bulk-chemistry and perovskite 


\section{0 $^{\text {th }}$ International Kimberlite Conference, Bangalore - 2012}

oxybarometry. Geological Journal DOI: 10.1002/ gj.1309.

CHALAPATHI RAO, N.V., WU, F.Y., MITCHELL, R.H., LI, Q.L. and LEHMANN, B. (2012) Mesoproterozoic U-Pb ages, trace element and $\mathrm{Sr}-$ $\mathrm{Nd}$ isotopic composition of perovskite from kimberlites of the Eastern Dharwar craton, southern India: distinct mantle sources and a widespread 1.1 Ga tectonomagmatic event (Chemical Geology; submitted).

COLLERSON, K.D., WILLIAMS, Q., EWART, A.E. and MURPHY, D.T. (2010) Origin of HIMU and EM-1 domains sampled by ocean island basalts, kimberlites and carbonatites: The role of $\mathrm{CO}_{2}$ fluxed lower mantle melting in thermochemical upwellings. Physics of the Earth and Planetary Interiors v.181, pp.112-131.

CONTICELLI, S., CARLSON, R.W., WIDOM, E. and SERRI, G. (2007) Chemical and isotopic composition ( $\mathrm{Os}, \mathrm{Pb}, \mathrm{Nd}$, and $\mathrm{Sr}$ ) of Neogene to Quaternary calc-alkalic, shoshonitic, and ultrapotassic mafic rocks from the Italian peninsula: inferences on the nature of their mantle sources. Geological Society of America Special Paper v.418, pp. 171-202.

DONNELLY, C.L., GRIFFIN, W.L., O'REILLY, S.Y., PEARSON, N.J. and SHEE, S.R. (2011) The kimberlites and related rocks of the Kuruman kimberlite Province, Kaapvaal craton, South Africa. Contributions to Mineralogy and Petrology v.161, pp. 351-371.

FRENCH, J.E., HEAMAN, L.M., CHACKO, T., SRIVASTAVA, R.K., (2007) 1891-1883 Ma Southern Bastar-Cuddapah mafic igneous events, India: A newly recognised large igneous province. Precambrian Res., v.160, pp. 308-322.

GRAHAM, S., LAMBERT, D.D., SHEE, S.R., SMITH, C.B. and REEVES, S. (1999) Re-Os isotopic evidence for Archaean lithospheric mantle beneath the Kimberley block, Western Australia. Geology v.27, pp. 431-434.

GRAHAM, S., LAMBERT, D. and SHEE, S. (2004) The petrogenesis of carbonatite, melnoite and kimberlite from the eastern Goldfields Province, Yilgarn craton. Lithos v.76, pp. 519-533.

LAMBERT, D.D., SHIREY, S.B. and BERGMAN, S.C. (1995) Proterozoic lithospheric mantle source for the Prairie Creek lamproites: Re-Os and Sm$\mathrm{Nd}$ isotopic evidence. Geology v.23, pp. 273-276.

LE ROEX, A.P., BELL, D.R. and DAVIS, P. (2003) Petrogenesis of Group I kimberlites from Kimberley, South Africa: evidence from bulk rock geochemistry. Journal of Petrology v.44, pp.22612286.

LEHMANN, B., BURGESS, R., FREI, D., BELYATSKY, B., MAINKAR, D., CHALAPATHI RAO, N.V. and HEAMAN, L.M. (2010) Diamondiferous kimberlites in central India synchronous with Deccan flood basalts. Earth and Planetary Science Letters v.290, pp.142-149.

MIRNEJAD, H. and BEL, K. (2006) origin and source evolution of the Leucite Hills lamproites: evidence from $\mathrm{Sr}-\mathrm{Nd}-\mathrm{Pb}-\mathrm{O}$ isotopic compositions. Journal of Petrology v. 47, pp. 2463-2489.

MITCHELL, R.H. (2006) Potassic magmas derived from metasomatised lithospheric mantle: nomenclature and relevance to exploration for diamond-bearing rocks. Journal of Geological Society of India v.67, pp.317-327.

MURPHY, D.T., COLLERSON, K.D. and KAMBER, B.S. (2002) Lamproites from Gaussberg, Antarctica: possible transition zone melts of Archaean subducted sediment. Journal of Petrology v. 43, pp. 981-1001.

NEELAKANTAM, S. (2001) Exploration for diamonds in southern India. Geological Survey of India Special v.58, pp.521-555.

OSBORNE, I., SHERLOCK, S., ANAND, M. and ARGLES, T., (2011) New Ar-Ar ages of southern Indian kimberlites and a lamproite and their geochemical evolution. Precambrian Research v. 189, pp. 91-103.

PATEL, S.C, RAVI, S., ANILKUMAR, Y. and PATI, J.K. (2010) Major element composition of concentrate garnets in Proterozoic kimberlites from the Eastern Dharwar Craton, India: implications on sub-continental lithospheric mantle. Journal of Asian Earth Sciences, v.39, pp. 578-588.

PATON, C., HERGT, J.M., WOODHEAD, J.D., PHILLIPS, D. and SHEE, S.R., (2009) Identifying the asthenospheric component of kimberlitic magmas from the Dharwar craton, India. Lithos v.112s, pp. 296-310.

PAUL D.K, NAYAK, S.S. and PANT, N.C. (2006) Indian kimberlites and related rocks: petrology and 


\section{0 $^{\text {th }}$ International Kimberlite Conference, Bangalore - 2012}

geochemistry. Jour Geol Soc India v.67, pp. 328355.

PAUL, D.K., CROCKET, J.H., REDDY, T.A.K. and PANT, N.C. (2007) Petrology and geochemistry including Platinum Group element abundances of the Mesoproterozoic ultramafic (lamproite) rocks of Krishna district, southern India: implications for source rock characteristics and ptrogenesis. Journal of the Geological Society of India, v.69, pp. 577596.

PEARSON, D.G., NOWELL, G.M., KJARSGAARD, B.A. and DOWALL, D.P. (2008) The genesis of kimberlite: geochemical constraints. Extended Abstracts $9^{\text {th }}$ International kimberlite conference, Frankfurt (No.9IKC-A-00149).

REDDY, T.A.K., SRIDHAR, M., RAVI, S. and CHAKRAVARTHY,V. (2003) Petrography and geochemistry of the Krishna lamproite field, Andhra Pradesh. Jour. Geol. Soc. India, v.61, pp.131-14.

RINGWOOD, A.R., KESSON, S.E., HIBBSERSON, W. and WARE, N. (1992) Origin of kimberlites and their related magmas. Earth and Planetary Science Letters v.113, pp.521-538.

RUDNICK, R.L. and WALKER, R.J. (2009) Interpreting ages from $\mathrm{Re}-\mathrm{Os}$ isotopes in peridotites. Lithos v.112, pp. 1083-1095.

SCHILLING; M., CARLSON, R.W., CONCEICAO, R.V., DANTAS, C. BERTOTTO, G.W. and E.KOESTER (2008) Re-Os isotope constraints on sub-continental lithospheric mantle evolution of southern South America. Earth and Planetary Science Letters v.268, pp. 89-101.

SHIREY, S.B. and WALKER, R.J. (1998) The Re-Os isotope system in cosmochemistry and hightemperature geochemistry. Annual Reviews of the Earth and Planetary Sciences v.26, pp. 423-500.
SMITH, C.B. (1983) Pb, Sr and Nd isotopic evidences for sources of southern African Cretaceous kimberlites. Nature v.304, pp. 51-54.

SRIDHAR, M., CHOWDHARY, V.S., NAYAK, S.S. and AUGUSTINE, P.F. (2004) Discovery of kimberlite pipes in Gadwal area, Mahuhbubnagar district, Andhra Pradesh. Journal of the Geological Society of India v.63, pp.95-99.

TAINTON, K.M. and MCKENZIE, D. (1994) The generation of kimberlites, lamproites and their source rocks. Journal of Petrology v.35, pp.787817.

TAPPE, S., PEARSON, D.G., NOWELL, G., NIELSON, T., MILSTEAD, P. and MUEHLENBACHS, K. (2011) A fresh isotopic look at Greenland kimberlites: Cratonic mantle lithosphere imprint on deep source signal. Earth and Planetary Science Letters doi: 10.1016/ j.eps12011.03.005

TORSVIK, T.H., BURKE, K., STEINBERGER, B., WEBB, S.J. and ASHWAL, L.D., (2010) Diamonds sampled by plumes from the core-mantle boundary. Nature v.466, pp. 352-355.

WALKER, R.J., CARLSON, R.W., SHIREY, S.B. and BOYD, F.R. (1989) Os, Sr, Nd, and Pb isotope systematics of southern African peridotite xenoliths: Implications for the chemical evolution of subcontinental mantle. Geochimica et Cosmochimica Acta v. 53, pp. 1583-1595.

WOODHEAD, J.D., HERGT, J.M., PHILLIPS, D. and PATON, C. (2009). African kimberlites revisited: in situ $\mathrm{Sr}$-isotope analysis of groundmass perovskite. Lithos v.112S, pp.311-317. 